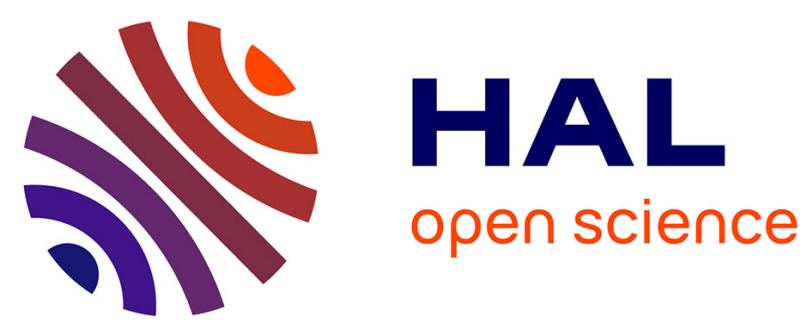

\title{
(Trifluoromethylselenyl)methylchalcogenyl as Emerging Fluorinated Groups: Synthesis under Photoredox Catalysis and Determination of the Lipophilicity
}

Kevin Grollier, Arnaud de Zordo-banliat, Flavien Bourdreux, Bruce Pegot, Guillaume Dagousset, Emmanuel Magnier, Thierry Billard

\section{To cite this version:}

Kevin Grollier, Arnaud de Zordo-banliat, Flavien Bourdreux, Bruce Pegot, Guillaume Dagousset, et al.. (Trifluoromethylselenyl)methylchalcogenyl as Emerging Fluorinated Groups: Synthesis under Photoredox Catalysis and Determination of the Lipophilicity. Chemistry - A European Journal, In press, 10.1002/chem.202100053 . hal-03183403

\author{
HAL Id: hal-03183403 \\ https://hal.science/hal-03183403
}

Submitted on 27 Mar 2021

HAL is a multi-disciplinary open access archive for the deposit and dissemination of scientific research documents, whether they are published or not. The documents may come from teaching and research institutions in France or abroad, or from public or private research centers.
L'archive ouverte pluridisciplinaire HAL, est destinée au dépôt et à la diffusion de documents scientifiques de niveau recherche, publiés ou non, émanant des établissements d'enseignement et de recherche français ou étrangers, des laboratoires publics ou privés. 


\title{
(Trifluoromethylselenyl)methylchalcogenyl as emerging fluorinated groups: synthesis under photoredox catalysis and determination of the lipophilicity.
}

\author{
Kevin Grollier, ${ }^{[a] \ddagger}$ Arnaud De Zordo-Banliat, ${ }^{[b] \ddagger}$ Flavien Bourdreux, ${ }^{[b]}$ Bruce Pegot, ${ }^{[b]}$ Guillaume \\ Dagousset, ${ }^{[b]}$ Emmanuel Magnier, ${ }^{*[b]}$ and Thierry Billard ${ }^{*[a][c]}$
}

Dedication ((optional))
[a] K. Grollier, Dr Th. Billard
Institute of Chemistry and Biochemistry (ICBMS, UMR CNRS 5246)
Univ Lyon, Université Lyon 1, CNRS, CPE, INSA
43 Bd du 11 novembre 1918, 69622 Villeurbanne (France)
E-mail: Thierry.billard@univ-lyon1.fr
[b] A. De Zordo-Banliat, F. Bourdreux, Dr B. Pegot, Dr G. Dagousset, Dr E. Magnier
Institut Lavoisier de Versailles (UMR CNRS 8180)
Université Paris-Saclay, UVSQ, CNRS
78035 Versailles (France)
E-mail: Emmanuel.magnier@uvsq.fr
[c] Dr Th. Billard
CERMEP-In vivo imaging
59 Bd Pinel, 69677 Lyon (France)
[†] These authors contributed equally to this work.

Supporting information for this article is given via a link at the end of the document.((Please delete this text if not appropriate))

\begin{abstract}
The synthesis of molecules bearing (trifluoromethylselenyl)methylchalcogenyl groups is described via an efficient two-step strategy based on a metal-free photoredox catalyzed decarboxylative trifluoromethylselenolation with good yields up to $88 \%$ which raised to $98 \%$ in flow chemistry conditions. The flow methods allowed also to scale up the reaction. The mechanism of this key reaction was studied. The physico-chemical characterization of these emerging groups was performed by determining their HanschLeo lipophilicity parameters with high values up to 2.24 . This reaction was also extended to perfluoroalkylselenolation with yields up to $95 \%$. Finally, this method was successfully applied to the functionalization of relevant bioactive molecules such as tocopherol or estrone derivatives.
\end{abstract}

\section{Introduction}

Since the fluorine discovery by Henri Moissan one century ago,,$^{[1]}$ fluorinated compounds have known a growing interest. ${ }^{[2]}$ Throughout these years, such substrates have demonstrated their successful usage in a large panel of applications, with a wide diversity from materials to life sciences. ${ }^{[3]}$

Nowadays, introduction of fluorinated substituents onto molecules is quite a staple in the design of new compounds for targeted applications. This is mainly due to the exclusive characteristics of fluorinated groups which confer to molecules specific properties in particular concerning physico-chemical and electronic aspects. ${ }^{[4]}$

In the objective to continue to propose new fluorinated moieties with modulative properties, the concept and development of "emerging fluorinated groups" appeared these last years, in particular by introducing heteroatoms. ${ }^{[5]}$ In this field, chalcogens are the most considered. Indeed, trifluoromethylchalcogenyl groups possess, inter alia, high Hansch-Leo lipophilicity parameters. ${ }^{[6]}$

If fragments with oxygen and sulfur were well studied, ${ }^{[5,7]}$ selenium derivatives were less developed until recently, ${ }^{[8]}$ maybe due to the toxicity associated to selenium ${ }^{[9]}$ However, selenium is an essential trace element for human biochemistry ${ }^{[10]}$ and selenoproteins play a crucial role in physiology for live species. ${ }^{[11]}$ In recent years, selenylated molecules have found promising applications in various fields such as, for instance, materials or drug design. ${ }^{[12]}$ Thus, recently, nonsteroidal antiinflammatory derivatives bearing a $\mathrm{CF}_{3} \mathrm{Se}$ group have been tested as potential anticancer agents with promising results. ${ }^{[13]}$

In our ongoing efforts to design of new fluorinated moieties with expected unknown properties, in particular concerning lipophilicity, we considered more sophisticated groups by merging another chalcogen with $\mathrm{CF}_{3} \mathrm{Se}$ group. In order to avoid weak chalcogenchalcogen bonds and to introduce some structural modularity, a methylene bridge between both heteroatoms was envisaged. Therefore, we focused our interest onto (trifluoromethylselenyl)methylchalcogenyl groups $\left(\mathrm{CF}_{3} \mathrm{SeCH}_{2} \mathrm{E} ; \mathrm{E}\right.$ $=\mathrm{O}, \mathrm{S}, \mathrm{Se}$ ).

\section{Results and Discussion}

The synthesis of molecules bearing these substituents was first considered. Visible light photocatalysis has emerged over the last decade as a powerful tool for the synthesis of various substrates in eco-friendly conditions. ${ }^{[14]}$ More specifically, photoredoxcatalyzed decarboxylation is an approach which was widely described and, in particular, the use of $\mathrm{R}-\mathrm{ECH}_{2} \mathrm{CO}_{2} \mathrm{H}$ substrates as starting materials was considered. ${ }^{[15]}$ Indeed, such substrates are easy to obtain by carboxymethylation of corresponding chalcogenols with haloacetate reagents. This strategy was 
perfectly adapted to our objective. The interest for such approach was confirmed during our study by the work of Zhang et al. which described the photoredox-catalyzed decarboxylative trifluoromethylselenolation of aliphatic carboxylic acids. ${ }^{[16]}$ Two examples of naphthyl- $\mathrm{ECH}_{2} \mathrm{SeCF}_{3}(\mathrm{E}=\mathrm{O}, \mathrm{S})$ compounds were described with medium yields. Nevertheless, this method is based on the use of $\left[\mathrm{CF}_{3} \mathrm{Se}\right]\left[\mathrm{NMe}_{4}\right]$ as anionic trifluoromethylselenolating reagent. This reagent suffers of some stability issues and its synthesis requires tedious conditions. ${ }^{[8 b, 17]}$ Furthermore, this decarboxylation required the use of one equivalent of NFSI as oxidant.

Trifluoromethylselenotoluenesulfonate $\left(\mathrm{CF}_{3} \mathrm{SeTs}, 1 \mathrm{1a}\right)$ was recently described as an electrophilic trifluoromethylselenolative reagent. ${ }^{[18]}$ Visible-light activation of this substrate to perform radical trifluoromethylselenolations was also performed. ${ }^{[19]}$ Consequently, the use of this reagent in the photoredox decarboxylation was postulated as a valuable alternative, which would avoid the addition of an oxidant. Such hypothesis was confirmed by the recently published decarboxylative cyanation of carboxylic acids based on the use of $\mathrm{TsCN}$ as reagent ${ }^{[20]}$ and an inexpensive and non-toxic derivative of vitamin $\mathrm{B}_{2}$ as organic photocatalyst. $^{[21]}$

Therefore, photoredox-catalyzed decarboxylative trifluoromethylselenolation was optimized with compound $\mathbf{2 b}$ as model substrate and riboflavin tetraacetate (RFTA) as photocatalyst.

Table 1. Reaction between $\mathbf{1 a}$ and $\mathbf{2 b}$ under photoredox conditions.

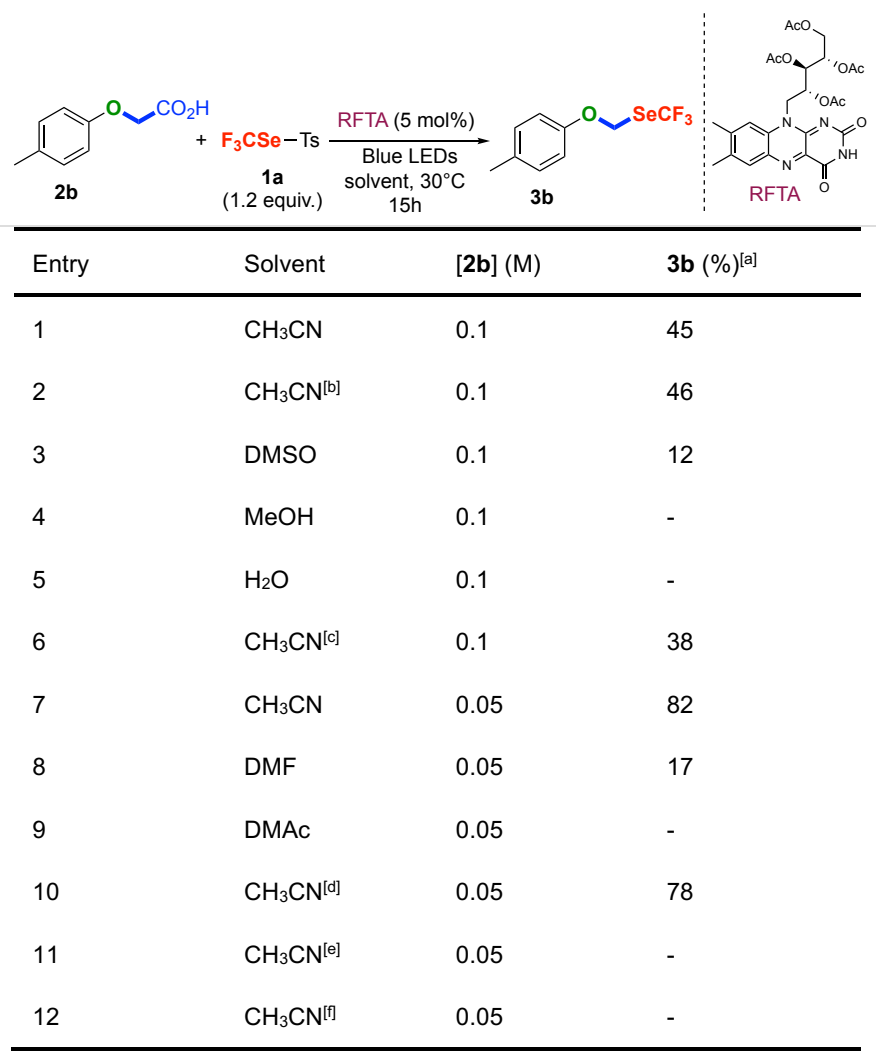

[a] Yield determined by ${ }^{19} \mathrm{~F} \mathrm{NMR}$ with $\mathrm{PhOCF}_{3}$ as internal standard. [b] with 10 mol\% of RFTA. [c] with 1 equiv. of $\mathrm{Cs}_{2} \mathrm{CO}_{3}$. [d] $24 \mathrm{~h}$. [e] without RFTA. [f] without irradiation.

Reaction led to the expected product $3 \mathrm{~b}$ with $45 \%$ yield in acetonitrile (Table 1, entry 1 ). Doubling the photocatalyst amount did not bring any improvements (Table 1 , entry 2). A more polar solvent as DMSO decreased considerably the yield (Table 1, entry 3) and protic solvents were deleterious for the reaction (Table 1, entries 4-5). The addition of $\mathrm{Cs}_{2} \mathrm{CO}_{3}$ as base decreased the observed yield (Table 1, entry 6). Interestingly, a dilution by half of the reacting medium gave rise to a better result of $82 \%$ (Table 1, entry 7), as previously observed in literature. ${ }^{[20]}$ This may be due to the high molar absorption coefficient of RFTA. Even in these diluted conditions, the use of more polar solvents clearly did not favor the reaction (Table 1, entries 8-9). No significant modifications were observed with an increase of reaction time (Table 1, entry 10). Finally, the compulsory uses of photocatalyst and blue LED irradiation were confirmed (Table 1, entries 11-12). With these optimal conditions in hand (Table 1, entry 7), several compounds were synthesized in batch and in flow conditions (Scheme 1).

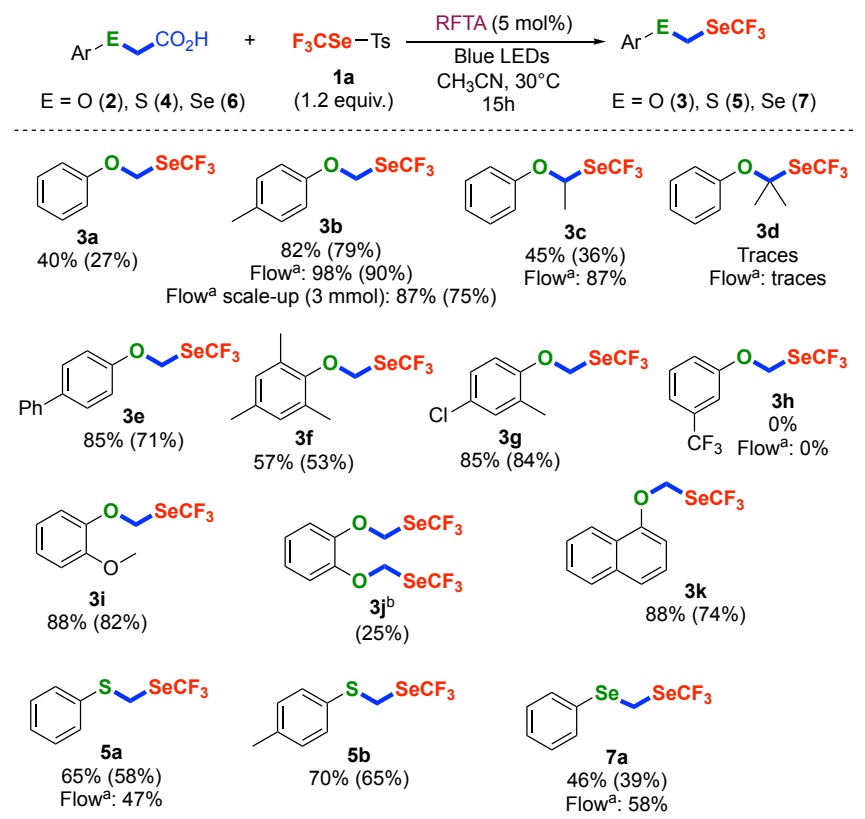

Scheme 1. Synthesis of $\mathrm{CF}_{3} \mathrm{SeCH}_{2} \mathrm{E}$-molecules $(\mathrm{E}=\mathrm{O}, \mathrm{S}, \mathrm{Se})$. Yields determined by ${ }^{19} \mathrm{~F} \mathrm{NMR}$ with $\mathrm{PhOCF}_{3}$ as internal standard; in parentheses, isolated yields. ${ }^{\text {a }}$ Flow rate of $167 \mu \mathrm{L} . \mathrm{min}^{-1}$ (residence time of $1 \mathrm{~h}$ ) at $25^{\circ} \mathrm{C}$. ${ }^{\mathrm{b}}$ with 2.4 equiv. of 1 a.

Globally, good results were obtained. If a slight steric hindrance did not have significant influence (3c), a more important one precluded the formation of the expected compound (3d). The presence of electron-donating group on the aromatic ring seems to favor the reaction $(\mathbf{3 b}, \mathbf{3 e - g}, \mathbf{3 i})$. In contrast, strong electronwithdrawing group as $\mathrm{CF}_{3}$ did not provide the expected product (3h). The reaction appears to be compatible with the presence of chlorine atom onto the aryl moiety $(\mathbf{3 g})$. Similar result was observed in naphthyl series (3k). Very original bis-adduct was also obtained, starting from the corresponding bis-carboxylic acid, albeit with moderate yield $(\mathbf{3 j})$. This reaction proved not limited to the oxygen atom and other chalcogens were also considered. Similar results were obtained with sulfur (5a-b) or selenium (7a). Everything else being equal, the yields are similar to those of oxygen.

In addition, this transformation was also performed with the use of continuous-flow reactor (Scheme 2). This technic is perfectly 
well adapted to photochemical transformations and scale-up experiments are facilitated under safer reaction conditions. ${ }^{[22]}$ After slight modifications of the reaction conditions, with a flow rate of $167 \mu \mathrm{L} . \mathrm{min}^{-1}$, the irradiation could be decreased to only $1 \mathrm{~h}$ of residence time, and the expected $\mathrm{CF}_{3} \mathrm{Se}$-product $\mathbf{3 b}$ was obtained in $98 \%$ yield. Furthermore, flow photoredox reactions are easier to scale-up than in batch conditions. Thus, the same experiment was performed on a larger scale (half a gram of starting carboxylic acid $-3 \mathrm{mmol}$ ) without any significant loss of the yield. In general, continuous flow provided a better yield (Scheme 1), in particular in the case of the more sterically hindered adduct 3 c ( $87 \%$ yield in flow, vs $45 \%$ in batch).

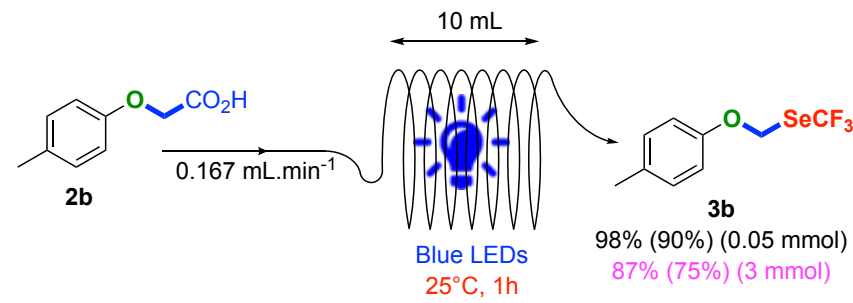

Scheme 2. Synthesis of ((p-tolyloxy)methyl)(trifluromethyl)selane (3b) using continuous flow.

Other fluoroalkylselenotoluenesulfonates reagents were also developed by one of our group with higher homolog of the fluorinated part. ${ }^{[18 a]}$ Consequently, the reaction was extended to others fluorinated reagents $\mathbf{1 b}$-c (Scheme 3 ).

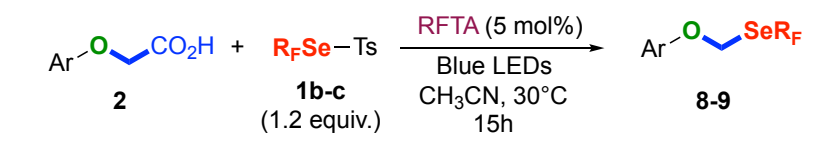

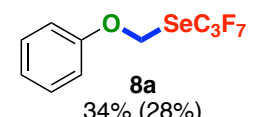

$34 \%(28 \%)$

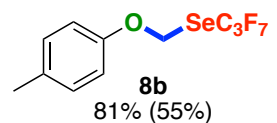

$81 \%(55 \%)$
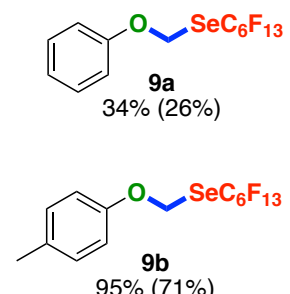

Scheme 3. Synthesis of $\mathrm{R}_{\mathrm{F}} \mathrm{SeCH} \mathrm{H}_{2} \mathrm{O}$-molecules. Yields determined by ${ }^{19} \mathrm{~F}$ NMR with $\mathrm{PhOCF}_{3}$ as internal standard; in parentheses, isolated yields.

Similar results to $\mathrm{CF}_{3}$ series were obtained with $\mathrm{C}_{3} \mathrm{~F}_{7}$ and $\mathrm{C}_{6} \mathrm{~F}_{13}$ moieties. These examples constitute the first examples of photoredox-catalyzed decarboxylative perfluoroalkylselenolation. Finally, this method was applied to some relevant bioactive compounds. Thus, eugenol, major component of clove bud oil used as local antiseptic and anesthetic, $\alpha$-tocopherol, component of vitamin $\mathrm{E}$ used as antioxidant, and estrone, a steroid estrogen hormone, were functionalized with $\mathrm{R}_{\mathrm{F}} \mathrm{SeCH}_{2} \mathrm{O}$ groups (Scheme 4).

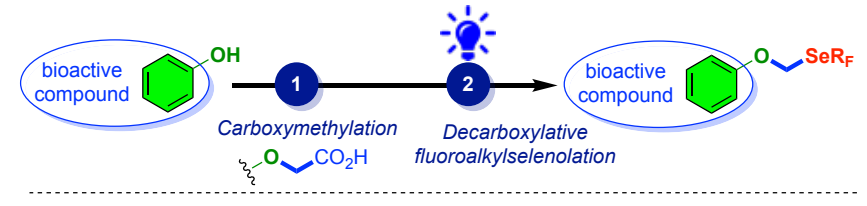

Eugenol derivative<smiles>C=CCc1ccc(OC[Ge]C(F)(F)F)c(OC)c1</smiles>

$\alpha$-Tocopherol derivative<smiles>Cc1c(C)c2c(c(C)c1OCC(F)(F)F)CCC(C)(CCCC(C)CCCC(C)CCCC(C)C)O2</smiles>

Estrone derivatives<smiles>CC12CCC3c4ccc(OCC(F)(F)F)cc4CCC3C1CCC2=O</smiles>

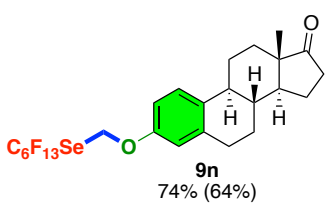

Scheme 4. Functionalization of some bioactive compounds. Yields determined by ${ }^{19} \mathrm{~F}$ NMR with $\mathrm{PhOCF}_{3}$ as internal standard; in parentheses, isolated yields.

Eugenol derivative (3I) was obtained in only moderate yield. A complex mixture was observed at the end of the reaction with some by-products arising from radical trifluoromethylselenolation of double bond, as previously described. ${ }^{[19 b]}$ Derivatization of tocopherol led also to a moderate result $(3 \mathrm{~m})$ which could be explained by steric hindrance as demonstrated in Scheme 1. Nevertheless, the result remains interesting in view of the complexity of molecule. Finally, with estrone good yield was observed in both trifluoromethyl (3n) and tridecafluorohexyl series $(9 n)$. This result demonstrates that not hindered aromatic ring favors the reaction and confirms the hypothesis put forward with tocopherol.

To better understand this decarboxylative trifluoromethylselenolation, a mechanistic study has been performed. As both light and photocatalyst were required for the reaction (Table 1, entries 11-12 and Scheme 5), a radical-based mechanism was hypothesized. This hypothesis was confirmed by a reaction quenched in presence of TEMPO (Scheme 5).

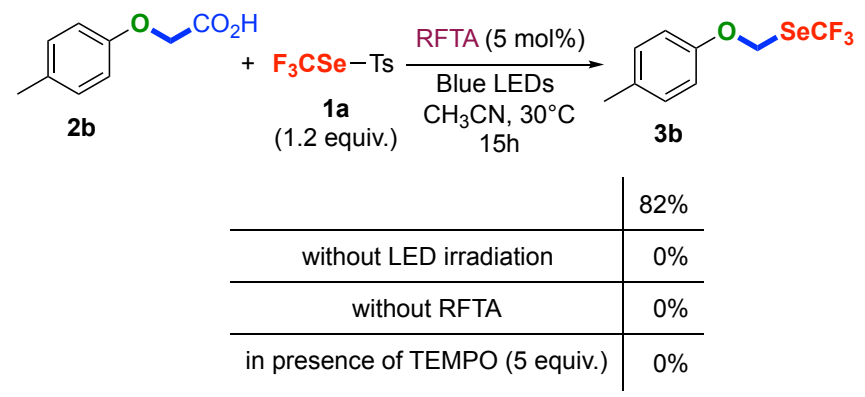

Scheme 5. Control reactions. 
Due to the high oxidation potential of the excited state of RTFA (E $=+1,67 \mathrm{~V}$ vs SCE), ${ }^{[23]}$ we envisioned an oxidative quenching cycle with carboxylic acids 2-4-6 $\left(E=+1.16 \mathrm{~V}\right.$ vs SCE). ${ }^{[24]}$ To confirm this hypothesis, fluorescence quenching experiments were performed with p-methylphenoxyacetic acid $\mathbf{2 b}$ and trifluoromethylselenotoluenesulfonate 1a (Figure 1). The quenching constant of 1a was calculated to be almost ten times less important $\left(\mathrm{k}_{\mathrm{q}(1 \mathrm{a})}=4.7 \times 10^{8} \mathrm{M}^{-1} \cdot \mathrm{s}^{-1}\right)$ than the quenching constant with $\mathbf{2 b}\left(\mathrm{k}_{\mathrm{q}(2 \mathbf{b})}=3.5 \times 10^{9} \mathrm{M}^{-1} \cdot \mathrm{s}^{-1}\right)$. This result indicated that RFTA $^{*}$ is mostly quenched by the carboxylic acid substrate. Finally, the quantum yield of the reaction was measured (see SI for more details). The maximum value $\Phi=0.23$ indicated that a photocatalytic pathway is favored over a radical chain mechanism.

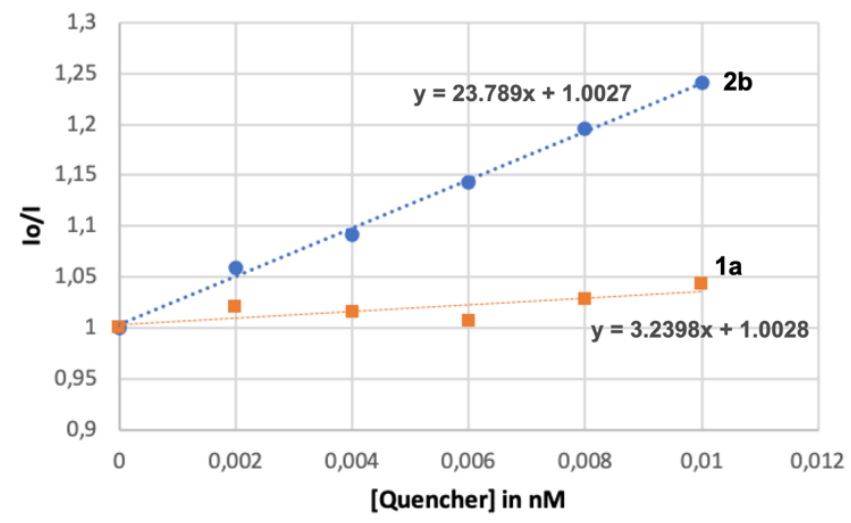

Figure 1. Fluorescence quenching experiments.

Based on these studies, a plausible mechanism was proposed (Scheme 6). First, the excited photocatalyst (RFTA*) performs a PCET (proton coupled electron transfer) with carboxylic acid 2, 4, or 6, leading to [RFTA-H] and O-centered radical intermediate I, which evolves into carbon-centered radical II after a fast decarboxylation step. Intermediate II then reacts with reagent $1 \mathrm{a}$ to form the desired product. The resulting $\mathrm{Ts}^{\bullet}$ radical is then reduced into $\mathrm{TsH}$ by $[\mathrm{RFTA}-\mathrm{H}]^{\circ}$, which regenerates the photocatalyst.

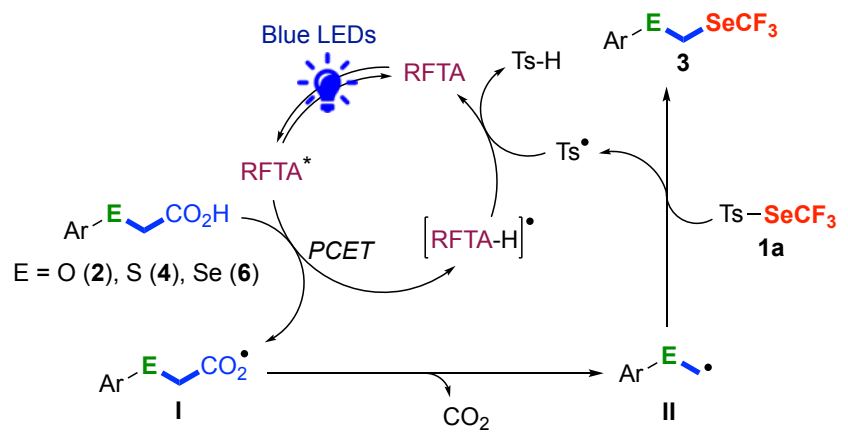

Scheme 6. Proposed mechanism.

In order to further study the properties of the (trifluoromethylselenyl)methylchalcogenyl groups, their HanschLeo lipophilicity parameters were determined. As previously described, ${ }^{[6]}$ octanol-water partition coefficient $(\log P)$ of substituted benzene $\mathbf{3 a}, \mathbf{5 a}$ and $\mathbf{7 a}$ were measured and compared to benzene (Figure 2). The measures were replicated several times and the mean values were obtained with a good standard deviation.

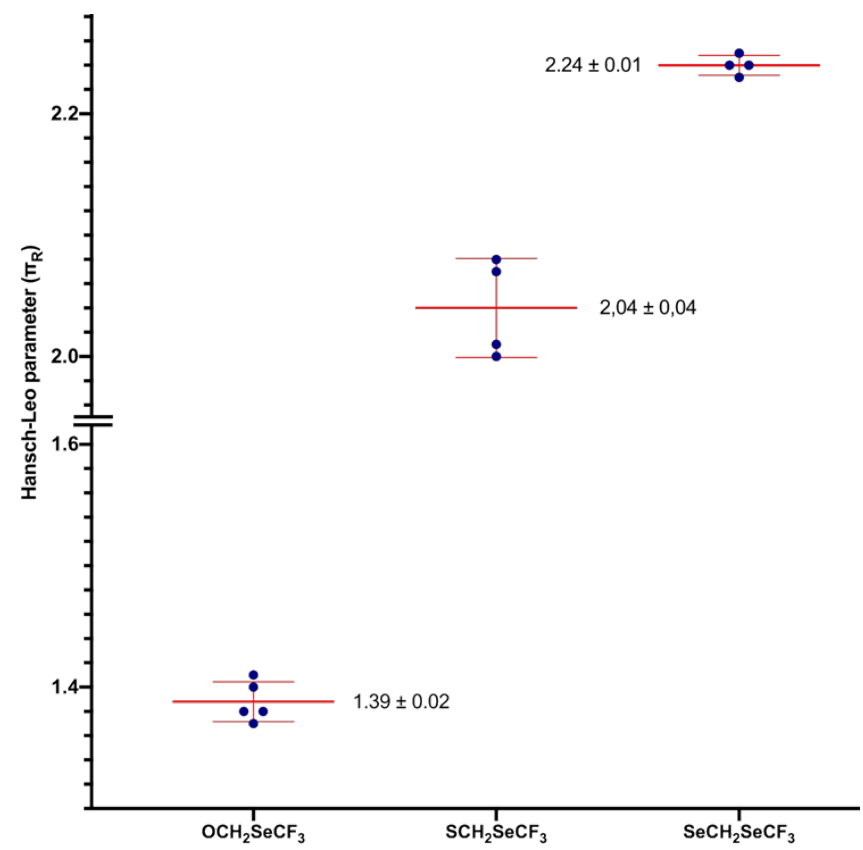

Figure 2. Hansch-Leo lipohilicity parameters $\left(\pi_{R}\right)$ of $\mathrm{CF}_{3} \mathrm{SeCH}_{2} \mathrm{E}$ groups. Scatter dot plot with means and standard deviations.

Compared to $\mathrm{CF}_{3} \mathrm{E}$ groups, lipophilicity of $\mathrm{CF}_{3} \mathrm{SeCH}_{2} \mathrm{E}$ groups is systematically increased (Table 2). Furthermore, the values grow with atomic number of chalcogen $(E)$. The evolution of the Hansch-Leo parameters demonstrates an additive effect of both chalcogen atom and $\mathrm{CH}_{2}$ moiety leading to a continuous increase of $\pi_{\mathrm{R}}$ parameters (Figure 3 ). Compared to $\mathrm{CH}_{2} \mathrm{SeCF}_{3}$, the addition of a second chalcogen generally increases $\pi_{\mathrm{R}}$ apart for oxygen because of the hydrophilic character of $\mathrm{OCH}_{2}$ moiety. Nevertheless, $\mathrm{ECH}_{2} \mathrm{SeCF}_{3}$ groups are more lipophilic than corresponding $\mathrm{ECF}_{3}$. Thus, the $\mathrm{SeCH}_{2} \mathrm{SeCF}_{3}$ moiety appears to be very lipophilic with a $\pi_{R}=2.24$ which constitutes one of the highest determined values for fluorinated groups.

Table 2. Hansch-Leo lipophilicity parameters $\left(\pi_{R}\right)$ observed by merging chalcogen(s) and $\mathrm{CF}_{3}$ group.

\begin{tabular}{llllll}
\hline $\mathrm{ECH}_{3}$ & $\pi_{\mathrm{R}}{ }^{[6]}$ & $\mathrm{ECF}_{3}$ & $\pi_{\mathrm{R}}{ }^{[6]}$ & $\mathrm{ECH}_{2} \mathrm{SeCF}_{3}$ & $\pi_{\mathrm{R}}{ }^{[a]}$ \\
\hline $\mathrm{CH}_{3}$ & 0.56 & $\mathrm{CF}_{3}$ & 0.88 & $\mathrm{CH}_{2} \mathrm{SeCF}_{3}$ & 1.63 \\
$\mathrm{OCH}_{3}$ & -0.02 & $\mathrm{OCF}_{3}$ & 1.04 & $\mathrm{OCH}_{2} \mathrm{SeCF}_{3}$ & 1.39 \\
$\mathrm{SCH}_{3}$ & 0.61 & $\mathrm{SCF}_{3}$ & 1.44 & $\mathrm{SCH}_{2} \mathrm{SeCF}_{3}$ & 2.04 \\
$\mathrm{SeCH}_{3}{ }^{[b]}$ & 0.74 & $\mathrm{SeCF}_{3}{ }^{[\mathrm{c}]}$ & 1.61 & $\mathrm{SeCH}_{2} \mathrm{SeCF}_{3}$ & 2.24 \\
\hline
\end{tabular}

[a] Determined in this paper, see supporting information. [b] log $\mathrm{P}$ calculated using Advanced Chemistry Development (ACD/Labs) Software V11.02 (C) 1994-2020 ACD/Labs). [c] re-evaluated value, see supporting information. 


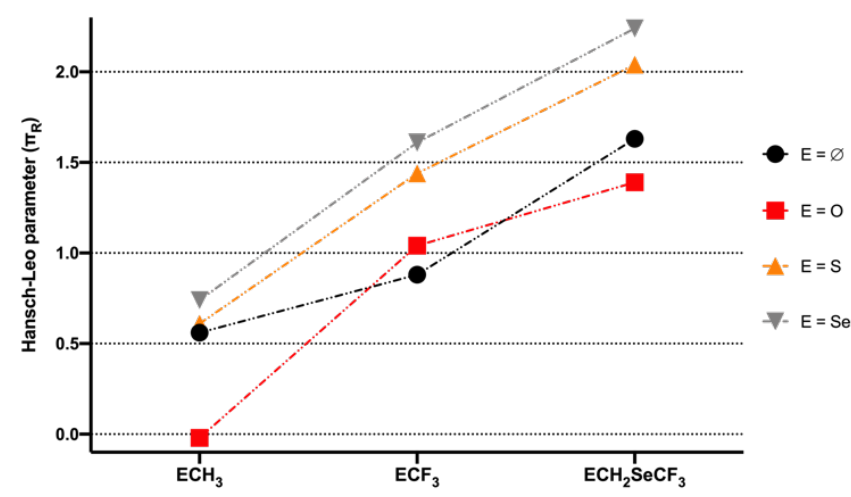

Figure 3. Hansch-Leo lipohilicity parameters $\left(\pi_{\mathrm{R}}\right)$ evolution.

\section{Conclusion}

(Trifluoromethylselenyl)methylchalcogenyl groups are innovative fluorinated substituents with high Hansch-Leo lipophilicity parameters. Their introduction onto organic molecules is easy to perform in two steps starting from corresponding chalcogenols via an efficient metal-free photoredox decarboxylative trifluoromethylselenolation as key step. This synthesis was optimized in flow conditions allowing rapid process easy to scaleup. These results demonstrate that not only the association of chalcogens and trifluoromethyl moiety remains a pertinent strategy to develop new fluorinated emerging groups with specific properties but also confirm, as already widely described in literature, that photoredox catalysis and flow chemistry constitute very efficient and well-adapted approaches in modern fluorine chemistry.

\section{Experimental Section}

Decarboxylative perfluoroalkylselenolation in batch conditions. To a tube equipped with a magnetic stir bar are added $\operatorname{TsSeR}_{\mathrm{F}}(\mathbf{1} ; 0.18 \mathrm{mmol}$ 1.2 equiv.), carboxylic acid $(\mathbf{2}, \mathbf{4}, \mathbf{6} ; 0.15 \mathrm{mmol}, 1$ equiv.) and RFTA (0.008 mmol, 0.05 equiv.) in $3 \mathrm{~mL}$ of dry $\mathrm{CH}_{3} \mathrm{CN}$ (previously sparged with $\mathrm{N}_{2}$ ). The tube is sealed with an adapted septum and the mixture is sparged for 5 min with a $\mathrm{N}_{2}$ balloon. The reaction mixture is then stirred for $15 \mathrm{~h}$ at $30^{\circ} \mathrm{C}$ under blue light irradiation. Conversion is checked by ${ }^{19} \mathrm{~F}$ NMR with $\mathrm{PhOCF}_{3}$ as internal standard. The reaction mixture is partitioned between $\mathrm{Et}_{2} \mathrm{O}$ or pentane and water, the combined organic layers are washed with brine, dried over $\mathrm{MgSO}_{4}$, filtered and concentrated under moderate vacuum. The crude residue is then purified by flash chromatography to afford the desired product $(\mathbf{3}, \mathbf{5}, \mathbf{7}, \mathbf{8}, \mathbf{9})$.

Decarboxylative trifluoromethylselenolation in flow conditions. To a tube under argon were added the carboxylic acid $(\mathbf{2}, \mathbf{4}, \mathbf{6} ; 0.1 \mathrm{mmol}, 1$ equiv.), $\mathrm{TsSeCF}_{3}$ (1a; $0.12 \mathrm{mmol}, 1.2$ equiv.) and RFTA (5.0 $\mu \mathrm{mol}, 0.05$ equiv.). $\mathrm{CH}_{3} \mathrm{CN}(2 \mathrm{~mL})$ was added and the solution is degassed with argon for $10 \mathrm{~min}$ and stirred at room temperature until full dissolution of reagents. Then, using an easy-Photochem E-series system from Vapourtec with a $10 \mathrm{~mL}$ reactor irradiated with a $450 \mathrm{~nm}$ LED system, $1 \mathrm{~mL}$ of the solution (0.05 mmol) was pumped at a flow rate of $167 \mu \mathrm{L} . \mathrm{min}^{-1}$ at $25^{\circ} \mathrm{C}$. The reaction mixture is collected and partitioned between $\mathrm{Et}_{2} \mathrm{O}$ or pentane and water, the combined organic layers are washed with brine, dried over $\mathrm{MgSO}_{4}$, filtered and concentrated under moderate vacuum. The crude residue is then purified by flash chromatography to afford the desired product.
Luminescence quenching experiments. A stock solution of photocatalyst was prepared by dissolving RFTA ( $3 \mathrm{mg}, 5 \mu \mathrm{mol}$ ) in $10 \mathrm{~mL}$ of $\mathrm{MeCN}$. Of this solution, $1 \mathrm{~mL}$ were further diluted with $\mathrm{MeCN}$ to give a total volume of $10 \mathrm{~mL}$ ([RFTA] $=5 \times 10^{-5} \mathrm{M}$ ). A stock solution of carboxylic acid $\mathbf{2 b}$ was prepared by dissolving $\mathbf{2 b}(100 \mathrm{mg}, 600 \mu \mathrm{mol})$ in $20 \mathrm{~mL}$ of $\mathrm{MeCN}\left([\mathbf{2 b}]=3 \times 10^{-2} \mathrm{M}\right)$. A stock solution of $\mathrm{TsSeCF}_{3} 1 \mathbf{a}$ was prepared by dissolving 1a (181 mg, $600 \mu \mathrm{mol})$ in $20 \mathrm{~mL}$ of MeCN ([1a] $\left.=3 \times 10^{-2} \mathrm{M}\right)$. For each experiment, 6 samples were prepared in the dark. Quartz cuvettes $(3.5 \mathrm{~mL})$ were filled with photocatalyst stock solution $(0.3 \mathrm{~mL})$, quencher stock solution ( $0 \mathrm{~mL}, 0.2 \mathrm{~mL}, 0.4 \mathrm{~mL}, 0.6 \mathrm{~mL}, 0.8 \mathrm{~mL}, 1.0 \mathrm{~mL}$ ) and $\mathrm{MeCN}(2.7 \mathrm{~mL}, 2.5 \mathrm{~mL}, 2.3 \mathrm{~mL}, 2.1 \mathrm{~mL}, 1.9 \mathrm{~mL}, 1.7 \mathrm{~mL})$ to obtain a total volume of $3 \mathrm{~mL}$. The final concentrations were $[\mathrm{RFTA}]=510^{-6} \mathrm{M}$ and [Quencher] $=2 \times 10^{-3} \mathrm{M}, 4 \times 10^{-3} \mathrm{M}, 6 \times 10^{-3} \mathrm{M}, 8 \times 10^{-3} \mathrm{M}, 1 \times 10^{-2} \mathrm{M}$. For each sample, emission spectra were acquired between $400 \mathrm{~nm}$ and 600 $\mathrm{nm}$ (excitation at $450 \mathrm{~nm})$. Rates of quenching $\left(\mathrm{k}_{\mathrm{q}}\right)$ were determined using Stern-Volmer kinetics: $I_{0} / l=k_{q} \tau_{0}[q u e n c h e r] ~+1$, where $I_{0}$ is the luminescence intensity without the quencher, $I$ is the intensity with the quencher, and $\tau_{0}$ is the excited state lifetime of the photocatalyst.

Determination of Hansch-Leo parameters $\left(\pi_{R}\right)$. To a $10 \mathrm{~mL}$ pear-shaped flask was added octanol (ca. $2 \mathrm{~mL}$ ), water (ca. $2 \mathrm{~mL}$ ) and the molecule to study (ca. $2 \mu \mathrm{L}$ ). The resulting biphasic mixture was hand-shacked for 5 $\mathrm{min}$ and then the flask was centrifuged for $5 \mathrm{~min}$ to enable complete phase separation. Using two syringes with needles, a sample was carefully taken from each layer. In particular for taking a water sample aliquot, a long needle with trocar was used. Upon reaching the water phase, the trocar was removed, the aliquot was taken with syringe and the needle quickly removed from the solution. Then a small amount of water phase was discarded (to ensure all traces of octanol were out of the needle). The needles were carefully wiped with dry tissue before the sample was transferred into the HPLC vial. Samples were injected in HPLC (eluent $\mathrm{MeOH} / \mathrm{H}_{2} \mathrm{O}$ ) with an UV detector. LogP was determined as the logarithm of the ratio between the peak areas of molecules in octanol and water. The Hansch-Leo parameter was calculated as $\pi_{\mathrm{R}}=\log \mathrm{P}$ (molecule $)$ $\log \mathrm{P}($ benzene).

\section{Acknowledgements}

This work was supported by a grant from the French National Research Agency (ANR 18-CE07-0039-01). The NMR Centre of the university of Lyon is thanked for their contribution. The authors are grateful to the CNRS and the French Ministry of Research for financial support. The French Fluorine Network (GIS-FLUOR) is also acknowledged for its support.

Keywords: Fluorine $•$ Selenium $•$ Photoredox $•$ Lipophilicity $•$ Decarboxylation

[1] a) H. Moissan, C. R. Hebd. Seances Acad. Sci. 1886, 102, 1543-1544; b) H. Moissan, C. R. Hebd. Seances Acad. Sci. 1886, 103, 202-205; c) H. Moissan, C. R. Hebd. Seances Acad. Sci. 1886, 103, 256-258; d) H. Moissan, Ann. Chim. Phys. 1887, 6, 472-537; e) H. Moissan, C. R. Hebd. Seances Acad. Sci. 1899, 128, 1543-1545.

[2] P. Kirsch, Modern Fluoroorganic Chemistry, Wiley-VCH, Weinheim, 2013.

[3] a) M. Pagliaro, R. Ciriminna, J. Mater. Chem. 2005, 15, 4981-4991; b) R. Berger, G. Resnati, P. Metrangolo, E. Weber, J. Hulliger, Chem. Soc. Rev. 2011, 40, 3496-3508; c) D. Chopra, T. N. G. Row, CrystEngComm 2011, 13, 2175-2186; d) P. Jeschke, Pest Management Science 2010, 66, 10-27; e) T. Fujiwara, D. O'Hagan, J. Fluorine Chem. 2014, 167, 1629; f) Y. Ogawa, E. Tokunaga, O. Kobayashi, K. Hirai, N. Shibata, iScience 2020, 23, 101467; g) Y. Zhou, J. Wang, Z. Gu, S. Wang, W. Zhu, J. L. Aceña, V. A. Soloshonok, K. Izawa, H. Liu, Chem. Rev. 2016, 116, 422-518; h) N. A. Meanwell, J. Med. Chem. 2018, 61, 5822-5880; i) H. Mei, J. Han, S. Fustero, M. Medio-Simon, D. M. Sedgwick, C. Santi, 
R. Ruzziconi, V. A. Soloshonok, Chem. Eur. J. 2019, 25, 11797-11819; j) M. Cheng, C. Guo, M. L. Gross, Angew. Chem. Int. Ed. 2020, 59, 5880 $5889 ;$ k) B. M. Johnson, Y.-Z. Shu, X. Zhuo, N. A. Meanwell, J. Med. Chem. 2020, 63, 6315-6386; I) J. Han, A. M. Remete, L. S. Dobson, L. Kiss, K. Izawa, H. Moriwaki, V. A. Soloshonok, D. O'Hagan, J. Fluorine Chem. 2020, 239, 109639

[4] B. E. Smart, J. Fluorine Chem. 2001, 109, 3-11.

[5] Emerging Fluorinated Motifs: Synthesis, Properties and Applications (Eds.: D. Cahard, J. A. Ma), Wiley, Weinheim, Germany, 2020.

[6] a) A. Leo, C. Hansch, D. Elkins, Chem. Rev. 1971, 71, 525-616; b) Q. Glenadel, E. Ismalaj, T. Billard, Eur. J. Org. Chem. 2017, 530-533.

[7] a) F. R. Leroux, B. Manteau, J.-P. Vors, S. Pazenok, Beilstein J. Org Chem. 2008, 4, 13; b) T. Besset, P. Jubault, X. Pannecoucke, T. Poisson Org. Chem. Front. 2016, 3, 1004-1010; c) A. Tilit, F. Toulgoat, T. Billard, Angew. Chem. Int. Ed. 2016, 55, 11726-11735; Angew. Chem. Int. Ed. 2016, 128, 11900-11909; d) H.-Y. Xiong, X. Pannecoucke, T. Besset, Chem. Eur. J. 2016, 22, 16734-16749; e) F. Toulgoat, T. Billard in Modern Synthesis Processes and Reactivity of Fluorinated Compounds Progress in Fluorine Science (Eds.: H. Groult, F. Leroux, A. Tressaud) Elsevier Science, London, United Kingdom, 2017, pp. 141-179; f) X.-H. Xu, K. Matsuzaki, N. Shibata, Chem. Rev. 2015, 115, 731-764.

[8] a) A. Tlili, E. Ismalaj, Q. Glenadel, C. Ghiazza, T. Billard, Chem. Eur. J. 2018, 24, 3659-3670; b) T. Billard, F. Toulgoat in Emerging Fluorinated Motifs: Synthesis, Properties and Applications (Eds.: D. Cahard, J. A. Ma), Wiley, Weinheim, Germany, 2020, pp. 691-721.

[9] M. J. Yaeger, R. D. Neiger, L. Holler, T. L. Fraser, D. J. Hurley, I. S. Palmer, J. Vet. Diagn. Invest. 1998, 10, 268-273.

[10] a) M. P. Rayman, Lancet 2000, 356, 233-241; b) EFSA Panel on Dietetic Products, Nutrition and Allergies, EFSA Journal 2014, 12, 3846; c) European Food Safety Authority, EFSA Supporting Publications 2017, 14, e15121E.

[11] a) K. M. Brown, J. R. Arthur, Public Health Nutr. 2001, 4, 593-599; b) S. Gromer, J. K. Eubel, B. L. Lee, J. Jacob, Cell. Mol. Life Sci. 2005, 62 2414-2437; c) V. M. Labunskyy, D. L. Hatfield, V. N. Gladyshev, Physiol. Rev. 2014, 94, 739-777; d) M. Erika, P. Alessandro, P. Enrica, Curr. Protein Peptide Sci. 2014, 15, 598-607; e) R. Mousa, R. Notis Dardashti, N. Metanis, Angew. Chem. Int. Ed. 2017, 56, 15818-15827.

[12] a) L. V. Romashov, V. P. Ananikov, Chem. Eur. J. 2013, 19, 1764017660; b) Q. Li, Y. Zhang, Z. Chen, X. Pan, Z. Zhang, J. Zhu, X. Zhu, Org. Chem. Front. 2020, 7, 2815-2841; c) W. Guo, Y. Fu, Chem. Eur. J. 2020, 26, 13322-13331; d) G. Mugesh, W.-W. du Mont, H. Sies, Chem Rev. 2001, 101, 2125-2180; e) N. Singh, A. C. Halliday, J. M. Thomas, O. V. Kuznetsova, R. Baldwin, E. C. Y. Woon, P. K. Aley, I. Antoniadou, T. Sharp, S. R. Vasudevan, G. C. Churchill, Nat. Commun. 2013, 4, 1332; f) J. B. T. Rocha, B. C. Piccoli, C. S. Oliveira, ARKIVOC 2017, 457 491; g) Organoselenium Compounds in Biology and Medicine: Synthesis, Biological and Therapeutic Treatments (Eds.: V. K. Jain, K. I. Priyadarsini), Royal Society of Chemistry, Croydon, UK, 2018; h) Z. Chen H. Lai, L. Hou, T. Chen, Chem. Commun. 2020, 56, 179-196; i) A. D. Landgraf, A. S. Alsegiani, S. Alaqel, S. Thanna, Z. A. Shah, S. J. Sucheck ACS Chem. Neurosci. 2020, 11, 3008-3016; j) V. Alcolea, S. PérezSilanes, Eur. J. Med. Chem. 2020, 206, 112673.

[13] X. He, M. Zhong, S. Li, X. Li, Y. Li, Z. Li, Y. Gao, F. Ding, D. Wen, Y. Lei, Y. Zhang, Eur. J. Med. Chem. 2020, 208, 112864

[14] a) Visible Light Photocatalysis in Organic Chemistry (Eds.: C. R. J. Stephenson, T. P. Yoon, D. W. C. MacMillan), Wiley-VCH, Weinheim Germany, 2018; b) P. Li, J. A. Terrett, J. R. Zbieg, ACS Medicinal Chemistry Letters 2020, 11, 2120-2130.

[15] Q. Q. Zhou, Y. Wei, L. Q. Lu, W. J. Xiao in Science of Synthesis Photocatalysis in Organic Synthesis, Vol. 1, Thieme Chemistry, Stuttgart, Germany, 2018, pp. 167-218.

[16] Q.-Y. Han, K.-L. Tan, H.-N. Wang, C.-P. Zhang, Org. Lett. 2019, 21 10013-10017.

[17] W. Tyrra, D. Naumann, Y. L. Yagupolskii, J. Fluorine Chem. 2003, 123 183-187.

[18] a) Q. Glenadel, C. Ghiazza, A. Tlili, T. Billard, Adv. Synth. Catal. 2017, 359, 3414-3420; b) C. Ghiazza, A. Tlili, T. Billard, Beilstein J. Org. Chem. 2017, 13, 2626-2630; c) C. Ghiazza, V. Debrauwer, T. Billard, A. Tili, Chem. Eur. J. 2018, 24, 97-100; d) X. Zhao, X. Wei, M. Tian, X. Zheng,
L. Ji, Q. Li, Y. Lin, K. Lu, Tetrahedron Lett. 2019, 60, 1796-1799; e) J. Liu, M. Tian, A. Li, L. Ji, D. Qiu, X. Zhao, Tetrahedron Lett. 2021, in press doi:10.1016/j.tetlet.2020.152809.

[19] a) C. Ghiazza, V. Debrauwer, C. Monnereau, L. Khrouz, M. Médebielle, T. Billard, A. Tlili, Angew. Chem. Int. Ed. 2018, 57, 11781-11785; Angew. Chem. 2018, 130, 11955-11959; b) C. Ghiazza, L. Khrouz, C Monnereau, T. Billard, A. Tlili, Chem. Commun. 2018, 54, 9909-9912; c) C. Ghiazza, C. Monnereau, L. Khrouz, M. Médebielle, T. Billard, A. Tlili, Synlett 2019, 30, 777-782; d) D. E. Yerien, S. Barata-Vallejo, A. Postigo, J. Fluorine Chem. 2020, 240, 109652.

[20] N. P. Ramirez, B. König, J. C. Gonzalez-Gomez, Org. Lett. 2019, 21 , 1368-1373.

[21] J. B. Metternich, R. J. Mudd, R. Gilmour in Science of Synthesis: Photocatalysis in Organic Synthesis, Vol. 1, Thieme Chemistry, Stuttgart, Germany, 2018, pp. 391-404.

[22] a) J. P. Knowles, L. D. Elliott, K. I. Booker-Milburn, Beilstein J. Org. Chem. 2012, 8, 2025-2052; b) Y. Su, N. J. W. Straathof, V. Hessel, T. Noël Chem. Eur. J. 2014, 20, 10562-10589; c) Z. J. Garlets, J. D. Nguyen, C. R. J. Stephenson, Isr. J. Chem. 2014, 54, 351-360; d) M. B. Plutschack, C. A. Correia, P. H. Seeberger, K. Gilmore in Organometallic Flow Chemistry (Ed.: T. Noël), Springer International Publishing, Cham, 2016 pp. 43-76; e) D. Cambié, C. Bottecchia, N. J. W. Straathof, V. Hessel, T. Noël, Chem. Rev. 2016, 116, 10276-10341.

[23] A. H. Tolba, F. Vávra, J. Chudoba, R. Cibulka, Eur. J. Org. Chem. 2020, 2020, 1579-1585.

[24] M. Galicia, F. J. González, J. Electrochem. Soc. 2002, 149, D46. 


\section{Entry for the Table of Contents}

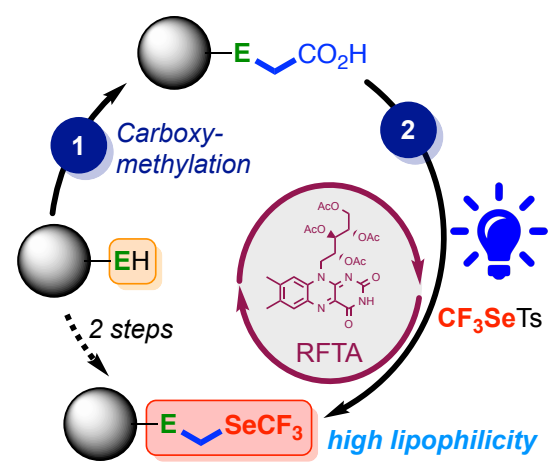

New, highly lipophilic, fluorinated groups. Through an easy two-step procedure, with photoredox-catalyzed decarboxylation key step, molecules with (trifluoromethylselenyl)methylchalcogenyl groups can be easily obtained. These new innovative substituents are among the highest lipophilic fluorinated moieties. 